\title{
FIRST RECORDS OF THE SLENDER SNIPE EEL, NEMICHTHYS SCOLOPACEUS (NEMICHTHYIDAE), AND THE ROBUST CUSK-EEL, BENTHOCOMETES ROBUSTUS (OPHIDIIDAE), FROM THE AEGEAN SEA
}

\author{
Murat BILECENOGLU ${ }^{1^{*}}$, Murat KAYA ${ }^{2}$, Erhan IRMAK ${ }^{2}$ \\ ${ }^{1}$ Department of Biology, Faculty of Arts and Sciences, Adnan Menderes University, Aydin, Turkey \\ ${ }^{2}$ Department of Hydrobiology, Faculty of Fisheries, Ege University, Bornova, Izmir, Turkey
}

Bilecenoglu M., Kaya M., Irmak E. 2006. First records of the slender snipe eel, Nemichthys scolopaceus (Nemichthyidae), and the robust cusk-eel, Benthocometes robustus (Ophidiidae), from the Aegean Sea. Acta Ichthyol. Piscat. 36 (1): 85-88.

\begin{abstract}
Two species previously unrecorded from the Aegean Sea, Nemichthys scolopaceus Richardson, 1848 and Benthocometes robustus (Goode et Bean, 1886), were captured during a bottom trawl off the Marmaris coasts (Turkey). These new records represent respectively the easternmost occurrence of $N$. scolopaceus and the second record of $B$. robustus from the eastern Mediterranean Basin.
\end{abstract}

Keywords: fish, zoogeography, Nemichthys scolopaceus, Nemichthyidae, Benthocometes robustus, Ophidiidae, Aegean Sea, new record

The southern Aegean Sea is an area zoogeographically distinct from rest of the Aegean Sea (eastern Mediterranean), due to presence of numerous islands, and unique bathymetrical and topographical features (Papaconstantinou 1988). The local ichthyofaunal diversity has increased within the last decade, primarily as a result of the establishment of exotic species and new records of deep-sea fishes (Bilecenoglu et al. 2002). Although there are several reasons for the increased number of alien fish, i.e., erythrean intrusion, shipping, mariculture, global warming, etc. (Galil and Zenetos 2002), enrichment of the Aegean Sea fauna by new deepwater fish is mostly as a result of modern trawling vessels, more extensive fishing effort, exploration of deeper areas, and intensified deep water studies (Papaconstantinou 1988, Kaya and Bilecenoglu 2000).

In this paper, we report the finding of two speciesNemichthys scolopaceus Richardson, 1848 and Benthocometes robustus (Goode et Bean, 1886) — previously unreported from the Aegean Sea and the Turkish coasts. Two specimens (one per species) were captured during the same bottom trawl by the commercial fishing vessel FETTAHIN MEHMET, at depths ranging from 550 to $600 \mathrm{~m}$ off the Marmaris coasts (southern Aegean Sea, Turkey, Fig. 1). Fish were fixed in $70 \%$ ethanol and preserved at Zoological Museum of Adnan Menderes University
(ZMADU). Measurements were carried out to the nearest $0.1 \mathrm{~mm}$ by a caliper, and meristic counts were made under the reflected light of a stereomicroscope. For the species identification, Nielsen $(1984,1986)$ and Nielsen et al. (1999) were used.

Nemichthys scolopaceus Richardson, 1848

Material examined: ZMADU-P/051, $820.5 \mathrm{~mm} \mathrm{SL}, 12$ April 2005, Marmaris coasts (southern Aegean Sea), lat $36^{\circ} 36^{\prime} 57^{\prime} \mathrm{N}$, long $28^{\circ} 19^{\prime} 48^{\prime \prime} \mathrm{E}, 550-600 \mathrm{~m}$ depth.

Diagnosis. Body extremely long, with caudal fin ending as filament (Fig. 2A). Anus located below pectoral fins. Dorsal-, caudal-, and anal fins confluent; base of dorsal fin rays at midbody strong and spine-like (Fig. 2B). Nontubular anterior nostril indicating unripe female specimen (Fig. 2C). Maximum body depth $0.98 \%$ of SL; head length $9.15 \%$ of SL; snout length $66.67 \%$ of head length; eye diameter $8.27 \%$ of head length. Dorsal fin origin located in front of pectoral fins, close to nape. Several irregular rows of pores on head: preopercular pores 9 , suborbital pores 16 and postorbital pores 11. Jaws with several small acute teeth, directed posteriorly. Teeth almost equal in size in lower jaw. Some larger teeth located on midline of upper jaw, with largest ones below anterior nos-

\footnotetext{
* Correspondence: Dr. Murat Bilecenoglu, Adnan Menderes Universitesi, Fen-Edebiyat Fakultesi, Biyoloji Bolumu, Hidrobiyoloji Anabilim Dali, 09010 Aydin, Turkey, phone: +90.256 .2128498 ext. 2212, fax: +90.256 .2135379 ,

e-mail: mbilecenoglu@adu.edu.tr or mbilecenoglu@yahoo.com
} 


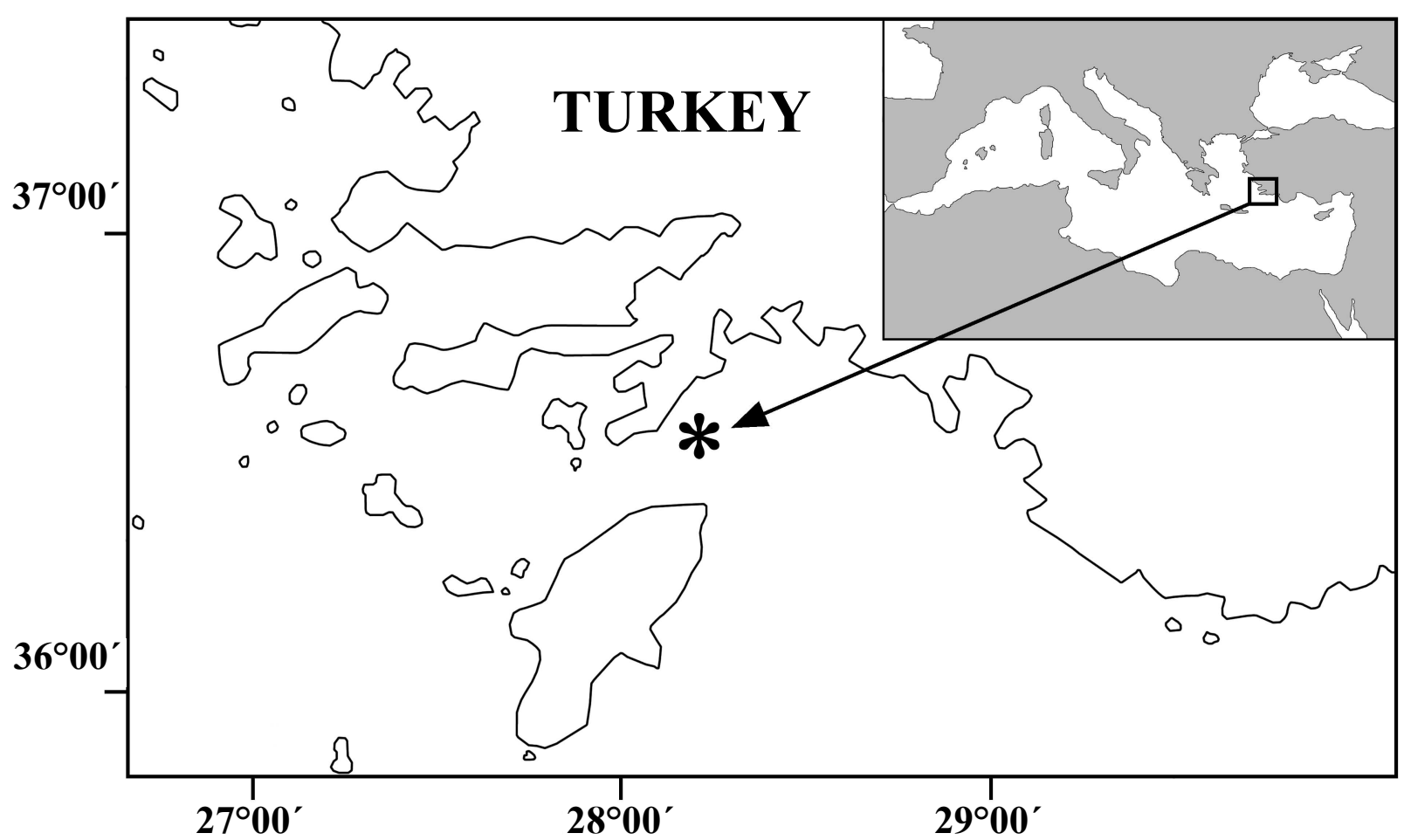

Fig. 1. Map showing the capture locality (indicated by an asterisk) of Nemichthys scolopaceus and Benthocometes robustus in the southern Aegean Sea

tril origin. Body pigmented on whole, but clearly darker below lateral line. Bases of dorsal- and anal fins dusky. Meristic counts and morphometric measurements in agreement with Nielsen (1984).

Distribution. Cosmopolitan in tropical and temperate seas; western Atlantic, from Nova Scotia to Brasil (Froese and Pauly 2006); eastern Atlantic from Iceland, Skagerrak, and Spain to southern Africa, including the western Mediterranean (Nielsen 1984, Froese and Pauly 2006); common in the Ligurian Sea, off Algerian and northern Sicilian coasts (Relini-Orsi and Relini 1973); occurring also in the Strait of Messina (Berdar et al. 1977), in southern Sardinian waters (Cau 1979), and in the eastern Ionian Sea (Mytilineou et al. 2005); reports available from northwest and eastern Pacific (Froese and Pauly 2006). N. scolopa-
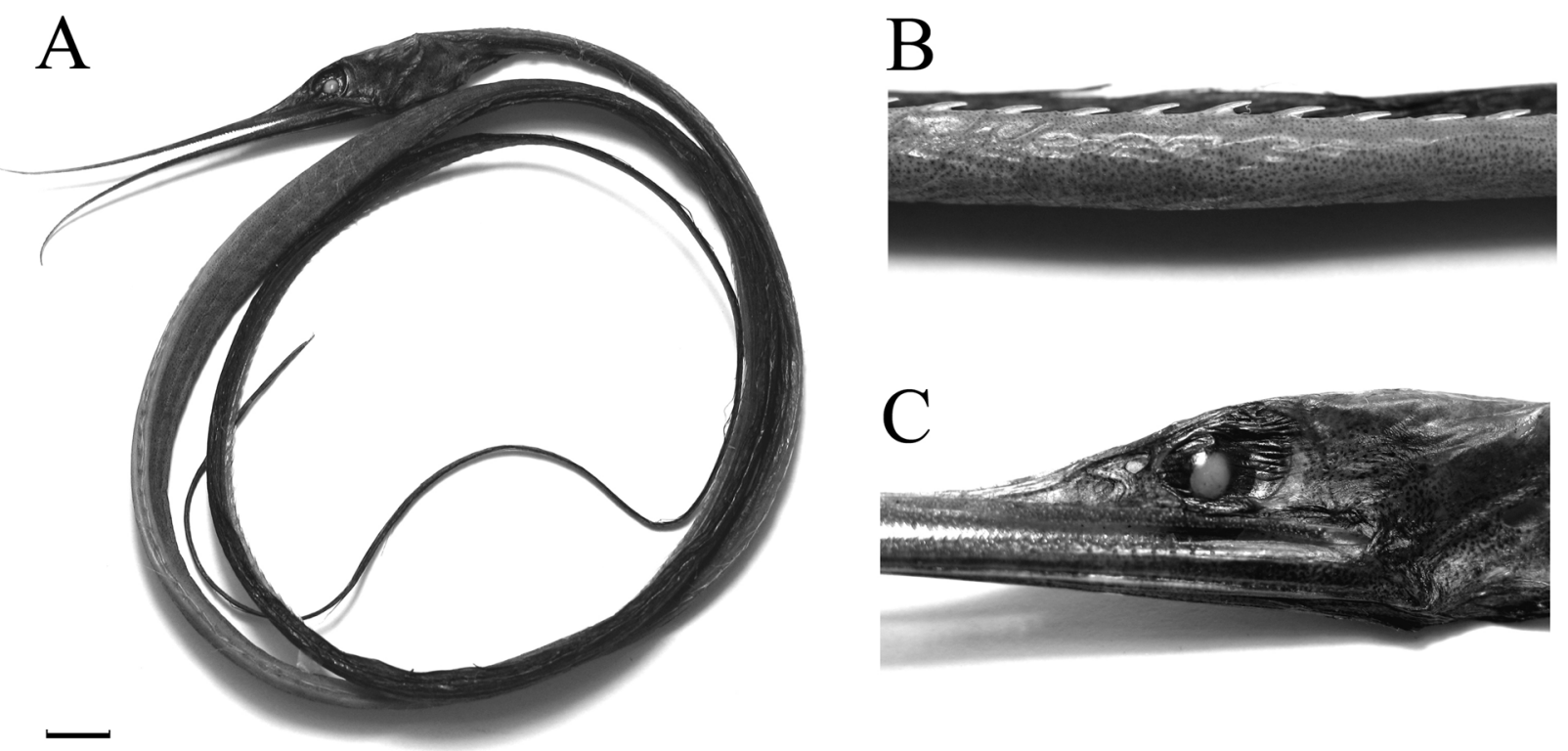

Fig. 2. Nemichthys scolopaceus, $820.5 \mathrm{~mm}$ TL, captured from southern Aegean Sea; (A) general view (scale bar $=1 \mathrm{~cm})$; (B) spinelike dorsal fin rays at the midbody; (C) head view 
ceus is an oceanic species, which may be encountered pelagically from surface to depths down to $2000 \mathrm{~m}$ (Nielsen 1984). Juveniles do not perform a vertical migration, which generally occur at depths down to $100 \mathrm{~m}$, but larger specimens $(>80 \mathrm{~mm})$ exhibit diurnal migration (Castonguay and McCleave 1987). According to Wippelhauser et al. (1996), small leptocephali (6-15 mm) of N. scolopaceus are abundant between February and April, and spawning occurs on both sides of thermal fronts throughout the western subtropical convergence zone of the Sargasso Sea. Maximum known size for this fish is $130 \mathrm{~cm}$ (Nielsen 1984). The species is recorded for the first time from both the eastern Mediterranean Basin and the Aegean Sea.

\section{Benthocometes robustus (Goode et Bean, 1886)}

Material examined: ZMADU-P/052, $110.9 \mathrm{~mm} \mathrm{SL}$ (120.3 mm TL), 12 April 2005, Marmaris coasts (southern Aegean Sea), lat $36^{\circ} 36^{\prime} 57^{\prime \prime} \mathrm{N}$, long $28^{\circ} 19^{\prime} 48^{\prime \prime} \mathrm{E}, 550-600$ m depth.

Diagnosis. Body short and stubby, tapering towards caudal fin (Fig.3). Head length $19.83 \%$ of SL; eye diameter $31.82 \%$ of head length, interorbital distance $85.71 \%$ of eye diameter; snout short and blunt, its length $13.60 \%$ of head length; predorsal length $28.85 \%$ of SL; preanal length $40.58 \%$ of SL; maximum body depth $23.44 \%$ of SL. Dorsal and anal fins united to caudal fin. A precise dorsal and anal fin-ray count could not be made; pectoral rays 29 , pelvic rays 2 , and caudal rays 15 . One of two pelvic rays elongate, its length $9.9 \%$ of SL. Operculum with two posteriorly directed spines; upper spine longer and pointed, lower spine relatively shorter and triangular in shape. Lateral line with ca. 100 scales, becoming indistinct towards caudal fin. Total of 12 transverse scales present above lateral line to origin of first dorsal fin. Jaws with numerous minute canine teeth; larger sized teeth only at outer margin of upper jaw, in uniserial band. Body covered with small cycloid scales; head, nape and operculum scaled. Body light brown in color; chin, snout, and pelvic areas much darker. Dorsal and fins dusky. Meristic counts and metric measurements in agreement with Nielsen et al. (1999).

Distribution. Tropical West Atlantic, off north-western Africa, western Mediterranean (Nielsen et al. 1999); Ba- learic Sea (D’Onghia et al. 2004); southern Sardinia (Cau 1979); Adriatic (Bello and Rizzi 1988); eastern Ionian Sea (Mytilineou et al. 2005); and Cyprus (Golani 1996). B. robustus is an uncommon benthopelagic species, distributing at depths ranging from 385 to $1200 \mathrm{~m}$ (Bello and Rizzi 1988, D’Onghia et al. 2004), but occurring mainly between 500 and $1000 \mathrm{~m}$ (Nielsen et al. 1999). Maximum total length reported for $B$. robustus is $15 \mathrm{~cm}$ (Froese and Pauly 2006). The species lacks a common name (see Nielsen 1986, Nielsen et al. 1999, Froese and Pauly 2006), therefore, a new name (robust cusk-eel) is proposed herewith. B. robustus is added for the first time to the Aegean Sea ichthyofauna.

\section{REFERENCES}

Bello G., Rizzi E. 1988. I Teleostei raccolti nell'Adriatico meridionale nelle campagne sperimentali di pesca a strascico 1985-1987. [Teleost fishes collected from southern Adriatic Sea during a survey on demersal fishes within 1985-1987.] Quaderni dell'Istituto Ricerche Pesca Marittima 5: 77-90. [ In Italian.]

Berdar A., Cavallaro G. Giuffre G., Potoschi A. 1977. Contributo alla conoscenza dei pesci spiaggiati lungo il litorale Siciliano dello stretto di Messina. [A contribution to the knowledge on the fishes occuring along the coast of Sicilia, along the Messina Strait.] Memorie di Biologia Marina e di Oceanografia 7: 77-87. [ In Italian.]

Bilecenoglu M., Taskavak E., Mater S., Kaya M. 2002. Checklist of the marine fishes of Turkey. Zootaxa 113: 1-194.

Castonguay M., McCleave J.D. 1987. Vertical distribution, diel and ontogenetic vertical migration and net avoidance of leptocephali of Anguilla and other common species in the Sargasso Sea. Journal of Plankton Research 9: 195-214.

Cau A. 1979. Primo contributo alla conoscenza dell'ittiofauna batiale dei mari della Sardegna meridionale. [First contribution to the knowledge of the deep-water ichthyofauna of southern Sardinia.] Rendiconti del Seminario della Facoltà di Scienze dell'Università di Cagliari 49: 585-595. [In Italian.]

D’Onghia G., Lloris D., Politou C.Y., Sion L., Dokos J. 2004. New records of deep-water teleost fishes in the Balearic Sea and Ionian Sea (Mediterranean Sea). Scientia Marina 68 (Supp. 3): 171-183.

Froese R., Pauly D. (eds.) 2006. Fishbase. World Wide Web electronic publication. http://www.fishbase.org

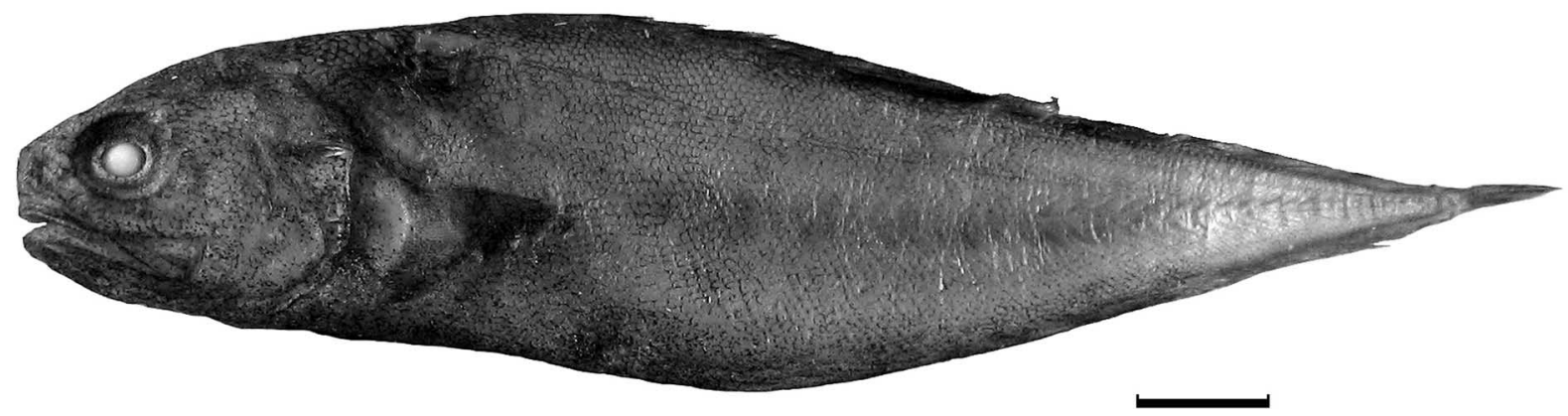

Fig. 3. Benthocometes robustus, $110.9 \mathrm{~mm} \mathrm{SL}$, captured from southern Aegean Sea (scale bar $=1 \mathrm{~cm}$ ) 
Galil B.S., Zenetos A. 2002. A sea change-Exotics in the eastern Mediterranean Sea. Pp. 325-336. In: Leppäkoski E., Olenin S., Gollasch S. (eds.) Invasive aquatic species of Europe: Distributions, impacts and management. Kluwer Academic Publishers, Dordrecht.

Golani D. 1996. The marine ichthyofauna of the eastern Levant - history, inventory and characterization. Israel Journal of Zoology 42: 15-55.

Kaya M., Bilecenoglu M. 2000. New records of deep-sea fish in Turkish seas and the eastern Mediterranean. Journal of Ichthyology 7: 543-548.

Mytilineou C., Politou C.-Y., Papaconstantinou C., Kavadas S., D'Onghia G., Sion L. 2005. Deep-water fish fauna in the eastern Ionian Sea. Belgian Journal of Zoology 135 (Suppl. 1): 229-233.

Nielsen J.G. 1984. Nemichthyidae. Pp. 551-554. In: Whitehead P.J.P., Bauchot M.-L., Hureau J.-C., Nielsen J., Tortonese E. (eds.) Fishes of the north-eastern Atlantic and the Mediterranean. Vol. 2. UNESCO, Paris.

Nielsen J.G. 1986. Ophidiidae. Pp. 1158-1166. In: Whitehead P.J.P., Bauchot M.-L., Hureau J.-C., Nielsen J., Tortonese E. (eds.) Fishes of the north-eastern Atlantic and the Mediterranean. Vol. 3. UNESCO, Paris.
Nielsen J.G., Cohen D.M., Markle D.F., Robins C.R. 1999. FAO species catalogue. Vol. 18. Ophidiiform fishes of the world (Order Ophidiiformes). An annotated and illustrated catalogue of pearlfishes, cusk-eels, brotulas and other ophidiiform fishes known to date. FAO Fisheries Synopsis No. 125: 1-178.

Papaconstantinou C. 1988. Check-list of marine fishes of Greece. Fauna Graeciae IV. Hellenic Zoological Society, Athens.

Relini-Orsi L., Relini G. 1973. Nuove segnalazioni di pesci nel mar Ligure e composizione dell'ittiofauna (Osteitti) dei fondi batiali strascicabili. [New records of fishes from the Ligurian Sea and the composition of demersal, deep-water ichthyofauna (bony fishes).] Bolletino dei Musei e degli Istituti Biologici dell'Università di Genova 41: 51-62. [In Italian.]

Wippelhauser G.S., Miller M.J., McCleave J.D. 1996. Evidence of spawning and the larval distributions of snipe eels (family Nemichthyidae) in the Sargasso Sea. Bulletin of Marine Science 59: 298-309.

Received: 31 May 2006

Accepted: 26 June 2006 